\title{
TITLE:
}

\section{A New Species of Deep-dwelling Razorfish from Japan}

$\operatorname{AUTHOR}(\mathrm{S}):$

Araga, Chuichi; Yoshino, Tetsuo

\section{CITATION:}

Araga, Chuichi ... [et al]. A New Species of Deep-dwelling Razorfish from Japan.

PUBLICATIONS OF THE SETO MARINE BIOLOGICAL LABORATORY 1986, 31(1-2): 75-79

ISSUE DATE:

1986-03-25

URL:

http://hdl.handle.net/2433/176116

RIGHT: 


\title{
A New Species of Deep-dwelling Razorfish from Japan
}

\author{
By \\ Chuichi Araga \\ Seto Marine Biological Laboratory, Kyoto University, Shirahama, \\ Wakayama, 649 22, Japan \\ and \\ Tetsuo Yoshino \\ Department of Marine Sciences, University of the Ryukyus, 1, Senbaru, \\ Nishihara-cho, Nakagami-gun, Okinawa Pref., 903-01, Japan
}

With Text-figure 1 and Table 1

This deep-dwelling razorfish was reported and illustrated for the first time by Masuda, Araga and Yoshino (1975) based on three specimens obtained from off Okinawajima, the Ryukyu Islands, but without identification. Yamakawa briefly described another specimen of this species in the book edited by Masuda et al. (1984) as Xyrichtys sp. Although this razorfish was thought to be endemic to the Ryukyu Islands, additional single specimen has been recently obtained from Ramapo Bank near the Ogasawara Islands. Closely examined these specimens, this fish is not identifiable with any known species. Here in this paper, the fish is described as new.

Type specimens of the new species have been deposited at the following institutions: Marine Sciences, University of the Ryukyus, Okinawa (URM); National Science Museum (Nat. Hist.), Tokyo (NSMT); and Seto Marine Biological Laboratory of Kyoto University, Shirahama, Wakayama Pref. (SMBL).

In the description of the new species, data in parentheses refer to paratypes. Measurement data of each specimen are given in the table 1 in which proportional measurements expressed as a percentage of standard length (SL) in parentheses. Terminology and counts follow Randall (1980), Russell and Randall (1981), and Russell (1985). Caudal fin counts are given as the number of upper unbranched rays in lowercase roman numerals + branched rays in arabic numerals + lower unbranched rays in lowercase roman numerals (eg. $\mathrm{ii}+10+\mathrm{ii}$ ). Pectoral fin counts are also given in the same manner.

We would like to express our thanks to Mr. Takeshi Yamakawa of the Kochi Senier High School for his courtesy to give us the chance describing this new species. Our thanks due to Mr. Eiichi Fujii of the Tokai Regional Fisheries Research Laboratory who kindly offered us an important specimen and its collecting data.

\section{Xyrichtys geisha sp. nov.}

(Japanese name: Kurobuchi-tensu)

(Fig. 1)

Hemipteronotus sp. 1 Masuda, Araga \& Yoshino, 1975, p. 306, Pl. 111-I.

Publ. Seto Mar. Biol. Lab., 31(1/2), 75-79, $1986 . \quad$ (Article 5) 
Xyrichtys sp. Yamakawa in Masuda et al. Ed., 1984, p. 205, Pl. 208-A.

Holotype: URM-P 7165, $347.0 \mathrm{~mm}$ SL, Itoman Fish Market (collected by a fisherman with hand line from the outer margin of Okinawa Trough, about $100 \mathrm{~m}$ deep), T. Yoshino, 7 May 1983.

Paratypes: NSMT-P 44107, $316.5 \mathrm{~mm}$ SL, Ramapo Bank off Ogasawara (Bonin) Islands, $95 \mathrm{~m}$ deep, vertical long line, E. Fujii, Sept. 1984; SMBL-F 73428, 74329, 73430, 323.2, 318.1, $281.7 \mathrm{~mm}$ SL, Naha Wholesale Market (fishing field same as that of the holotype), T. Yoshino, 27 Dec. 1973.

D i g $\mathrm{n}$ os is: Dorsal rays IX, 12; anal rays III, 12; caudal rays $\mathrm{ii}+10$ or $11+\mathrm{ii}$; pectoral rays $\mathrm{ii}+10$ or $11+\mathrm{i}$; pelvic rays 1,5 ; lateral line scales 19 or $20+5$; gill rakers 6 or $7+16$ to 18 . Easily distinguished from other species of the genus by its peculier coloration i.e. dorsal and ventral sides of body black, other parts of head and body olive yellow; dorsal, anal and pelvic fins entirely black; lower half of caudal fin also black; pectoral fin white except for black base.

Description: Dorsal rays IX, 12 ; anal rays III, 12 ; caudal rays $\mathrm{ii}+11$ (10 in one paratype) $+\mathrm{ii}$; pectoral rays $\mathrm{ii}+10$ (11 in one paratype $)+\mathrm{i}$; pelvic rays I,5; lateral line interrupted, the anterior upper portion with 20 (19) pored scales, lower posterior part with 5 pored scales; scales above lateral line to origin of dorsal fin $2+$ a half-sized scale; scales below lateral line to origin of anal fin $9+2$ or 3 small scales; gill rakers $7+11: 18$ (6 or $7+10: 16$ or 17$)$.

Body high, the depth 2.66 (2.47-2.60) in SL, and strongly compressed, the width 2.55 (2.48-2.80) in depth; head large, its length $3.10(3.10-3.22)$ in SL; snout length $2.73(2.72-3.51)$ in head length; eye diameter 6.48 (5.75-6.99) in head; interorbital space much convex, the width 4.08 (4.10 4.69) in head; caudal peduncle about 1.5 times as deep as long, the least depth 2.20 (2.08-2.21) in head.

Forehead roundly projected, anterior profile of head steep, the leading edge sharp; mouth terminal, the gape horizontal, posterior end of maxilla not reaching a vertical at frontal edge of eye; head naked except for a single row of small scales below lower edge of eye; gill membranes united each other, free from itshmus. Nostrils small, in front of lower fourth of eye, the anterior in a short fleshy tube, the posterior larger and triangular in shape. A pair of large, projecting, slightly recurved canine teeth at the tip of each jaw; lower pair inserted into a space between fairly separated upper canine teeth when the mouth closed; 8 to 10 conical teeth in a single row along the side of both jaws.

Lateral line interrupted, the end of anterior upper portion reaching a vertical at the base of 9 th dorsal soft ray; posterior lower part running from just below the base of last dosal soft ray to caudal fin base; few anterior scales on anterior upper lateral line with branched tubules, remaining lateral line scales with a single tubule.

Origin of dorsal fin just above the center of eye; 1st and 2nd dorsal spines slightly produced, somewhat remote but joined with the following spines by a low membrane; origin of anal fin below the base of 2 nd or 3rd dorsal soft ray, 1st anal spine short and slender, 3rd anal spine about 1.5 times as long as the 1st; all dorsal and anal soft rays branched, the last to its base; caudal fin short, the length of unscaled portion contained about 2.5 to 2.8 times in head length; posterior margin of caudal fin slightly rounded; pectoral fin rather large, 1.37 (1.37-1.49) in head length, the 4th ray 
Table 1. Proportional measurements of type specimens of Xyrichtys geisha.

\begin{tabular}{|c|c|c|c|c|c|}
\hline & \multirow{2}{*}{$\frac{\text { HOLOTYPE }}{\text { URM-P } 7156}$} & \multicolumn{4}{|c|}{ PARATYPES } \\
\hline & & NSMT-P 44107 & SMBL-F 73428 & SMBL-F 73429 & SMBL-F 73430 \\
\hline Standard length (mm) & 347.0 & 316.5 & 323.2 & 318.1 & 281.7 \\
\hline Body depth & $130.4(37.6)$ & $122.7(38.8)$ & $130.5(40.4)$ & $122.2(38.4)$ & $113.8(40.4)$ \\
\hline Body width & $51.2(14.8)$ & $49.4(15.6)$ & $46.6(14.4)$ & $45.6(14.3)$ & $41.1(14.6)$ \\
\hline Head length & $113.4(32.7)$ & $98.5(31.1)$ & $104.2(32.2)$ & $98.9(31.1)$ & $93.6(33.2)$ \\
\hline Snout length & $41.6(12.0)$ & $36.2(11.4)$ & $41.0(12.7)$ & $28.2(8.9)$ & $32.3(11.5)$ \\
\hline Eye diameter & $17.5(5.0)$ & $15.4(4.9)$ & $15.9(4.9)$ & $17.2(5.4)$ & $13.4(4.8)$ \\
\hline Interorbital width & $27.8(8.0)$ & $24.0(7.6)$ & $22.2(6.9)$ & $23.7(7.5)$ & $20.0(7.1)$ \\
\hline Length of upper jaw & $34.3(9.9)$ & $30.6(9.7)$ & $30.4(9.4)$ & $27.4(8.6)$ & $23.8(8.4)$ \\
\hline Depth of caudal peduncle & $51.5(14.8)$ & $47.3(14.9)$ & $47.7(14.8)$ & $46.7(14.7)$ & $42.3(15.0)$ \\
\hline Length of 1st dorsal spine & $52.3(15.1)$ & $48.3(15.3)$ & $46.4(14.4)$ & $45.3(14.2)$ & broken \\
\hline Length of 2 nd dorsal spine & $44.5(12.8)$ & $41.4(13.1)$ & $41.8(12.9)$ & $42.4(13.3)$ & $35.8(12.7)$ \\
\hline Length of 9 th dorsal spine & $40.8(11.8)$ & $40.1(12.7)$ & $40.0(12.4)$ & $40.4(12.7)$ & $36.5(12.9)$ \\
\hline Length of longest dorsal ray & $44.9(12.9)$ & $41.9(13.2)$ & $42.4(13.1)$ & $43.6(13.7)$ & $40.2(14.3)$ \\
\hline Length of dorsal fin base & $264.9(76.3)$ & $235.9(74.5)$ & $237.6(73.5)$ & $250.0(78.6)$ & $210.9(74.9)$ \\
\hline Length of 1st anal spine & $15.5(4.5)$ & $15.4(4.9)$ & $15.7(4.9)$ & $16.8(5.3)$ & $17.2(6.1)$ \\
\hline Length of 3rd anal spine & $25.8(7.4)$ & $26.2(8.3)$ & $27.1(8.4)$ & $28.0(8.8)$ & $29.8(10.6)$ \\
\hline Length of longest anal ray & $49.4(14.2)$ & $40.0(12.6)$ & $43.6(13.5)$ & $44.0(13.8)$ & $37.8(13.4)$ \\
\hline Length of anal fin base & $128.0(36.9)$ & $127.2(40.2)$ & $114.6(35.5)$ & $112.5(35.4)$ & $103.7(36.8)$ \\
\hline Length of caudal fin & $56.0(16.1)$ & $48.9(15.5)$ & $47.2(14.6)$ & $49.3(15.5)$ & $46.8(16.6)$ \\
\hline Length of pectoral fin & $82.7(23.8)$ & $69.6(22.0)$ & $74.8(23.1)$ & $72.1(22.7)$ & $62.7(22.3)$ \\
\hline Length of pelvic spine & $29.4(8.5)$ & $25.0(7.9)$ & $24.0(7.4)$ & $26.3(8.3)$ & $23.6(8.4)$ \\
\hline Length of pelvic fin & $51.7(14.9)$ & $37.1(11.7)$ & $38.7(12.0)$ & $43.7(13.7)$ & $37.4(13.3)$ \\
\hline
\end{tabular}




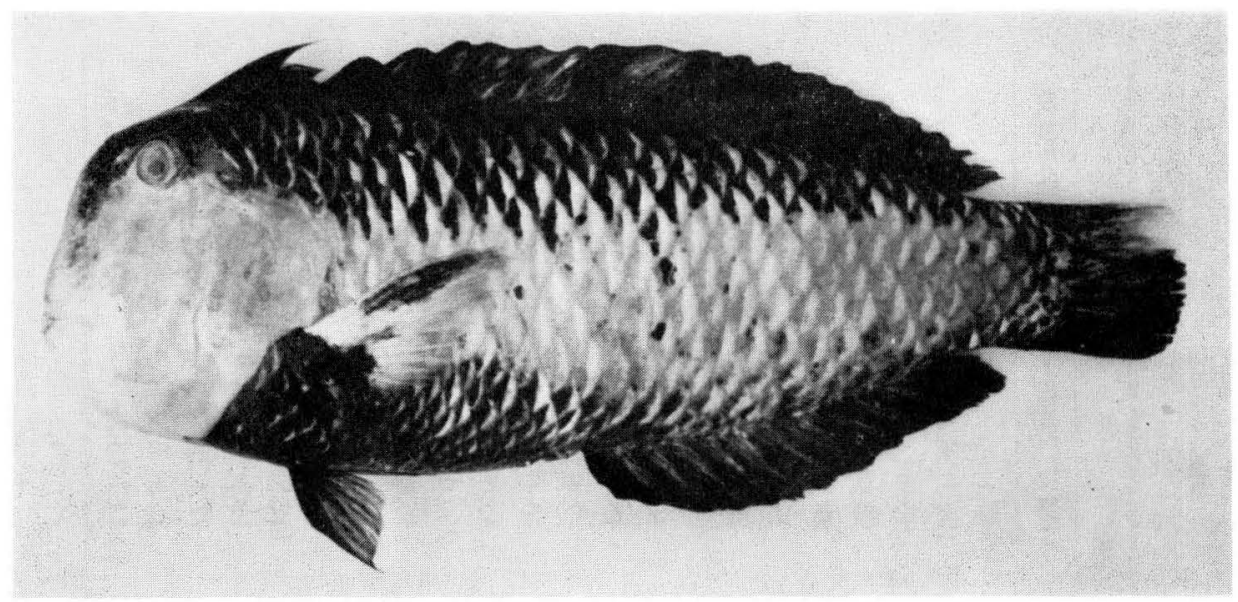

Fig. 1. Xyrichtys geisha sp. nov., holotype, 347 mm SL, URM-P 7165, Okinawajima.

longest; origin of pelvic fins below highest extent of pectoral base; the length 2.19 (2.26-2.69) in head, pelvic spine rather slender.

Color when fresh: Most of head and body light olive yellow, sometimes slightly pinkish with several black spots on median side of body; posterior margin of each sclae of these parts whitish; scales on back and belly jet black with pale posterior margin, then back and belly black as a whole; thorax and pectoral base entirely black; upper part of head blackish brown with a yellowish oblique band just behind eye; cheek with faint irregular blue lines; lips whitish; iris yellowish orange. Dorsal and anal fins black except for faint basal part of soft portions; upperhalf to two thirds of caudal fin blackish basally, yellowish white distally; lower one third to half of caudal fin black; pectoral fins slightly bluish white with jet black base (a black band along the upper margin in the holotype); pelvic fins black basally, somewhat faint distally.

Color in preservative: Most of head and body entirely pale yellowish; black portions of scales on back and belly, and black spots on median side of body when fresh change to dark brown; thorax darker than back and belly; dorsal, anal, lower part of caudal and pelvic fins all dark brown; pectoral fins pale yellowish with blackish base (faint dark brown band along the upper margin in the holotype).

E t y m o lo g y: Named geisha from the Japanese for "professional beauty and entertainer" in reference to the black and white coloration of this Fish that is imaginable for an elderly geisha dressed up with traditional costume.

\section{References}

Bleeker, P. 1862. Atlas ichthyologique, des Indes Orientales Néèlandaises. Vol. 1. xxi $+168 p p$. Frèdèric Muller, Amsterdam.

De Beaufort, L.F. 1940. The fishes of the Indo-Australian Archipelago. Vol. 8. xv+508pp. E.J. Brill, Leiden.

Fowler, H.W. \& B.A. Bean. 1928. Contribution to the bilogy of the Philippine Archipelago and 
adjacent regions. The fishes of the famliies Pomacentridae, Labridae and Callyodontidae. Bull. U.S. Nat. Mus. $100(7): 1-525$.

Masuda, H., C. Araga, \& T. Yoshino. 1975. Coastal fishes of southern Japan. 379pp. Tokai University Press, Tokyo.

, K. Amaoka, C. Araga, T. Ueno, \& T. Yoshino Ed. 1984. The fishes of the Japanese Archipelago. 437pp., 370pls. Tokai University Press, Tokyo.

Randall, J.E. 1965. A review of the razorfish genus Hemipteronotus (Labridae) of the Atlantic Ocean. Copeia, 1965, No. 4: 487-501.

- 1980. Two new Indo-Pacific labrid fishes of the genus Halichoeres, with notes on other species of the genus. Pacific Sci. 34(4): 415-432.

Russell, B.C. 1985. Revision of the Indo-Pacific labrid fish genus Suezichthys, with descriptions of four new species. Indo-Pacific Fishes, No. 2: 1-21.

- - \& J.E. Randall. 1981. The labrid fish genus Pseudolabrus from islands of Southern Pacific, with description of a new species from Rapa. Pacific Sci. 34(4): 433-440.

Schmidt, P.J. 1930. Fishes of the Riu-Kiu Islands. Trans. Pac. Comm. Acad. Sci. USSR, 1:19-155.

Schultz, L.P., and collaborators. 1960. Fishes of the Marshall and Marianas islands. Bull. U.S. Nat. Mus. 202(2): 1-438. 